Reviews

\title{
Financing Change: The Financial Community, Eco-efficiency, and Sustainable Development. By S. Schmidheiny and F. Zorraqu'n, with the World Business Council for Sustainable Development (1996) Cambridge, MA: The MIT Press. xxiv, 211 pp.
}

\section{Reviewed by Jerry A. Moles, Global Renaissance, LLC, Oakland, California.}

The emergence of the World Business Council for Sustainable Development establishes a long-needed movement within the business community by members who appreciate the uniqueness and fragile nature of life. Landscapes are being changed and water flows directed through human controlled diversion schemes that often destroy existing biodiversity within the oceans, rivers, and wetlands. The world's forests have been in decline since the emergence of iron tools in the hands of our ancestors, and we have changed much of Nature into agriculture. We frequently cannot locate ourselves in the larger evolutionary process because we are blinded by the immediacy of our positions as observers. It is difficult for many of us to judge cause-andconsequence beyond our lifetimes.

For those of us who have engaged sustainability as our mission, we appreciate the responsibility demonstrated by Schmidheiny and Zorraqu'n as they ask the business community to address environmental costs as they invest their resources and modify natural communities in order to serve human need, comfort, and symbolic ends. Not only do they ask for environmental accounting. They also evaluate contemporary efforts within the financial and business communities and suggest a number of next steps if the wealth of nations is to be invested in maintaining sustainable habitats.

The Council was formed in 1995. It resulted from a merger between the Business Council for Sustainable Development in Geneva and the World Industry Council for the Environment in Paris, the two organizations that led the business community response to the 1992 UN Conference on Environment and Development in Rio de Janeiro. With more than 120 members from 35 countries, representing 20 major industrial sectors, the WBCSD is a profound voice. The membership is a listing of global movers and shakers, Volkswagen AG, Fiat Auto S,p.A.K., Anova Holdings AG, Thai Farmers Bank, Ciba-Geigy AG, National Westminster Bank plc, Mitsubishi Corporation, NEC Corporation, Sony Corporation, Indonesian Wood Panel Association, Samsung Electronics, DuPont Company Inc., 3M Company, Monsanto Company, Weyerhaeuser, Xerox, S.A. Garovaglio y Zorraqu'n, AT \& T, The Dow Chemical Company, to name a few.

The negotiations following the 1992 Rio Summit have focused upon the protection of biodiversity and sustainable development. At the same time, there has been a great concern within the environmental community that the people who currently manage natural resources have a poor conservation record, as evident in the alarming rate of continued habitat destruction.

In response to that concern, Schmidheiny and Zorraqu'n speak to the pivotal position of the financial and business communities in using their resources prudently. The authors demonstrate that, far from monolithic, the "business community" is made up of a diverse set of arenas and players (financial markets, company leaders, investors and analysts, bankers, insurers, accountants, and raters). The authors explicate specific mechanisms of environmental change associated with each of these categories of actors, and suggest next steps that could be taken by each to strengthen environmental protection efforts globally.

The authors' Holy Grail is "eco-efficiency," getting "more" out of "less." This concept is said 


\section{Reviews}

to sum up the idea of sustainable development at the company level. As our awareness of our environmental limits has grown, numerous examples have emerged, demonstrating greater use benefit from a given volume of material, e.g., changes in wood processing technology to use more of the total tree (boards to chipped bark) or increased fuel efficiency in car engines.

Clearly, eco-efficiency must be a goal of the business community because, with continued population growth and the accompanying increase in the demand for natural resources, resource scarcity and higher costs are inevitable. Schmidheiny and Zorraqu'n raise a fundamental question for those who control much of the world's capital: "Are the world's financial markets and those who work in and around them a force for sustainable human progress, or are they an impediment against it?" (need page \#)

Of course, such an encompassing question cannot be answered immediately or in simple terms, but rather by each company in specific landscapes and watersheds. Schmidheiny and Zorraqu'n propose human practices that they claim will sustain current biodiversity and improve environmental quality. It is clear to them that "there is sufficient evidence to support the view that many of our current activities are not sustainable in the long term and that they stifle opportunity for a sizable proportion of the world's fast-expanding population" (need page \#).

From this position, they relate their question to the behavior of the financial market: does a short-term 'profit-only' mentality control market activities at the expense of both environment and human need? Or is it the case that the market, as a medium of human expression, will eventually reflect disquiet over poverty and the degradation of nature through social and environmental responsible companies? While these are fundamental questions in terms of human institutions, unless mechanisms are defined to counter forces of environmental degradation in favor of longterm sustainability, the results are likely to be hollow rhetorical chimes in the ancient cathedrals of our minds.

Schmidheiny and Zorraqu'n have a plan, based upon their interpretation of the demand for safer and more healthy environments. The opportunities to externalize environmental costs are being limited through the efforts of environmental activists, demands that the polluters pay, court rulings that owners of firms who finance and manage polluters are responsible for clean-up, and laws that protect both species and environmental processes. Thus, according to Schmidheiny and Zorraqu'n, the major players must get on the bandwagon. The bottom-line is that there are no other alternatives, we must live within our lifesphere. The market recognizes environmental risks and costs as an increasingly important element in financial evaluations, both in terms of increasing liabilities through fines, taxes, and potential costly rehabilitation efforts, and in terms of a changing global climate with increasingly unpredictable and costly catastrophic natural events. The insurance industry has absorbed substantial financial losses, sharpening its interest in climate change. And, as Schmidheiny and Zorraqu'n point out, when one member of the financial community takes a major loss, all those cooperating with that member also feel the effects. The financial community, to protect its own interest, must learn to protect the resources they are dependent upon for their own survival. Conservation and sustainable management must be shown to be successful business strategies, as continuing to discount future benefits on behalf of immediate gratification will lead to continued environmental degradation, probably at an accelerated rate because of population growth.

How do Schmidheiny and Zorraqu'n propose that we gain this elevated perspective? The key is where the money goes. The energy of our institutions is the capital flow, which is managed to benefit the owners of the wealth invested. What will the wealthy give in exchange for participating in the remaining living system(s)? What must be foregone in favor of environmental and social stability and long-term sustainability?

In Schmidheiny and Zorraqu'n's vision of the future, everyone must be prepared for capital penetration into their sphere of operation. They note, "developing regions are already liberalizing trade and foreign investment regimes while pursuing privatization schemes and opening new financial markets" (need page \#). Thus, environmental problems require market solutions. The questions they pose on behalf of the world's capitalists are: If money is invested, will there be a 
Reviews

return with interest? Will you allow me to buy or financially control natural and human resources within your regime? Will you assist me in protecting my wealth and my position within the financial and business community?

The challenge for the proponents of market solutions is to develop investment portfolios that encourage the sustainable use of natural resources and restore threatened landscapes and species. The opportunity for investment is expanding as 63 developing economies have liberalized their trade policy since the GATT talks began in 1985. The word is out that those who do not get in on the capital flow will shiver in the long dark night of poverty. As a consequence of these policy changes, investment is safer and trade more secure. Risk, the scary dragon in the business community, is reduced ö what was once uncertain is now probabilistic • at least in theory. Allies have been identified by the business communities in these countries. USAID contractors promote agricultural and technology trade between the rich and poor nations. Increasing foreign investment in control of land in developing nations demonstrates the consequences of changes in trade and financial policies. More than 30 nations liberalized their foreign direct investment requirements in 1991 alone, more than 60 have active privatization programs, and more than 50 have established capital markets in the nineties. Thus, capital has an arena designed for its benefit and the benefit of allies within the emerging economies. In their summary of the current success and the future, Schmidheiny and Zorraqu'n note:

Innovative partnerships among companies, governments, and multilateral agencies are providing capital in new ways: public-private financing partnerships, financial-sector reform programs, and privatization schemes with technical help. Emerging-economy governments are beginning to push through their own programs of investment guarantees, energy service programs, convertible grants, and support for venture capital programs. But a great deal more needs to be done (need page number).

Within this scenario, what needs to be done is the continual reduction of risk. Especially when Schmidheiny and Zorraqu'n adopt McKinsey's estimate that the developing economies will need an investment of $\$ 2$ trillion over the next ten years, the demand by potential investors to be secure with their wealth and position will be raised several octaves. The World Bank and other institutional lenders suggest that we may be witnessing the start of a large portfolio shift to the developing economies, ... , if confidence in emerging markets can be re-established following the Mexican crisis and more recent South American and Asian financial down-turns. While insignificant in terms of the global economy, there are a few sustainable investment funds whose experiences are potential guides for the future. For example, the Environmental Enterprises Assistance Fund of Arlington, Virginia operates as a not-for-profit venture capital fund investing in environmental and economic sustainable enterprises.

According to Schmidheiny and Zorraqu'n, business leaders in both developed and developing economies must develop eco-efficiency strategies and establish strong relationships with all the stakeholders to improve communication. Owners, managers, and people influenced by corporate decisions must be actively involved in understanding current conditions and future alternatives. The green customer is recognized for his/her power in the marketplace in terms of how companies have benefited from recognizing their demand for responsible and safe environmental management. Schmidheiny and Zorraqu'n recognize the market as a tougher master than a government which can be lobbied and influenced. This perspective gives clear indication of how business views its position within the halls of government. They conclude "More and more, the market is becoming the ultimate arbiter of success, and more and more the market itself is demanding eco-efficiency" (need page numbers) Once company leadership is in line, the investors and analysts must develop the capacity to interpret environmental costs, benefits, and risks. This is essential in order to protect the investors. The bankers have commented in a "Statement by Banks on the Environment and Sustainable Management" and, at the same time, have been found liable in court for the clean-up costs involving companies in which they held equity shares. They too 


\section{Reviews}

must encourage customers to become eco-efficient which, in turn, protects the banks' outstanding loans and existing services. As noted earlier, the insurance industry has been hard hit because of environmental consequences. U.S. insurers are facing an estimated $\$ 2$ trillion in pollution cleanup and asbestos-related claims. This coupled with the costs and continual threats of climate change has resulted in the creation of financial tools to allow businesses to "off-load" some of its environmental risks and reduce exposure to possible consequences of global warming. If we pursue this scenario, then businesses with high environmental risks cannot be insured and will disappear due to their inability to protect against loss. This requires that the accountants learn environmental cost and benefit accounting so rational business decisions can be made which protect the shared interests of corporate bodies and their stakeholders. In turn, the raters who evaluate the past and expected performance of firms must develop environmental standards of evaluation . Can an environmental rating as reliable as existing credit ratings be developed? To be effective, the raters must move well past uncertainty into experience on the ground with the necessary information resources to first explain and then predict loss.

In the Schmidheiny and Zorraqu'n's scenario, government has its role in creating a climate sensitive to and protective of investor capital. At the same time, government is expected to maintain a level playing field insofar as possible and express the will of the community through its actions in protecting both people and environment. Incentives are preferred over regulatory activity in that it allows creative business response to environmental concerns.

Given the existing options and the wealth present in the investment market, there is no alternative but to welcome the work and insight of Schmidheiny and Zorraqu'n and the WBCSD. To be successful, plans must be developed for watersheds, river basins, and the oceans in which the environmental costs and benefits are known in their own terms as opposed to their transposition into economic terms. Environmental consequences are ultimately more important than economic consequences. In real terms, they're the same thing viewed by different perspectives. Reliable information is necessary if company leaders, insurers, bankers, accountants, and raters are to make informed decisions. We must know in unambiguous terms how much soil is being lost under what types of cultural practices in which watersheds. We need to know who the polluters are and the costs of cleaning up their mess and changing their practices. We can do no less than request the same environmental standards of everyone. In this instance, less is more, less pollution is more safety and health. The effects of pollution are immediate and direct even though the chain of events initiated by pollution and environmental modification are often more difficult to ascertain. The definition of pollution is simple, pollution is that which diminishes the vibrancy and robustness of living biodiversity ö pollution is that which causes of to be less than we can potentially be.

Exploring sustainable investment opportunities is the place to start. In addition to joining a dialog, collaboration on sustainable projects is required. Schmidheiny and Zorraqu'n have provided a concise view of what is required to establish a sustainable economy from the perspective of the financial market. How do the remainder of the stakeholders - all of us - pick up this challenge and play an active role in achieving sustainable resource management and protecting existing biodiversity? Within the environmental community there is agreement that monitoring will be required to detect change and there must be reliable information available to investors and consumers which will allow them to support sustainable endeavors. How such information services will be supported on a global scale remain unanswered. Further, procedures to establish and enforce environmental performance standards to the satisfaction of stakeholders is an immediate challenge. Ultimately, biodiversity and environmental quality are the measures of success.

Regardless of your interpretation of utopia or of living safely within the limits of Nature, Financing Change deserves wide readership because of the clarity of expression and the leadership it demonstrates within a community that has the most to gain by protecting the status quo. This book demonstrates that the business community understands the threats of loss of biodiversity and environmental quality. At the same time, they are asking that the remainder of the global 
Reviews

community be open to their investments on behalf of the markets and clients that they serve. Even though our sense of equality and the right to live require that we not speak of population growth in terms which favor one community, ethnic group, nation, religion, or race over another, the fact remains that the number of humans on Earth continues to grow. Some communities even promote population growth as a way to protect their tradition and access to resources.

Capitalism and global markets have created systems of exploitation and trade which dictates much of modern environmental management. What acreage goes to black tea or to coconuts? The number of Brazil nuts that can be sold determines the harvest. The value of the harvest determines the lands dedicated to its production, and the wages paid to the agricultural workers are based upon local living conditions and economic alternatives. We are being told that the management of lands for Brazil nuts, the protection of natural areas within the remaining forests of the world on behalf of existing biodiversity, and the holding the threat of dire poverty at bay for all of the world's peoples can be influenced to become sustainable by changing the way money is invested. We are being told that the markets can be tuned to another set of information, that of the environment and its long term viability.

The next discussions should be about what is to be saved and in what condition the things saved will continue to exist. Are we talking about a future Nature that exists only within zoos, large and small? Or are we talking about learning to live with what remains and gradually allowing Nature to take more of her course as we move to occupy less of Her space and more efficiently use what is at our disposal? Or are we moving blindly ahead saying that we will figure it out as we go? It becomes every person's responsibility to protect the Life that remains. My question to the business community is "are you prepared to live by the consequences as we act to preserve simultaneously Nature and our place within that Nature?" Information costs are likely to be high because of the complexity of what is being managed -- a film of living tissue spread across a planet. The more situationally specific the information, the more likely a proposed solution will bring about the desired results. Thus, sensory input on changing conditions must reflect changes which threaten living systems in all places on Planet Earth. How will powerful institutions be sensitive to local conditions? How will the financial market determine if current biodiversity remains on a tea estate in the Uva Basin of highland Sri Lanka? As we get our financial house in order, we must likewise get our environmental house in order. Only after we look to the Earth and decide what needs to be done can we suggest to business the management costs in environmental and economic terms. Much that remains within the Life sphere on the surface of the Earth is already dedicated to human consumption.

How do we restrain our needs and aspirations? Not only are there financial markets, there are also consumer markets upon which the financial markets depend. Business people move between and among markets putting together the organizations which promote their participation in the financial and commercial sphere. In playing the markets, business must inspire needs and raise aspirations for their products and services. The great transition is moving from the position of what human wealth can afford economically to the position of what can be afforded environmentally with accounting done on a global scale. Business must learn to value products and services on the basis of what is preserved in their production and use. Only then will market serve in the protection of Life on Earth. If you buy from this market, we will all survive longer and, hopefully, in Peace.

Journal of Political Ecology

Vol. 61999 